\title{
Öğretmen Adaylarının Eğitim 4.0'a Karşı Algı ve Tutumlarının Belirlemesine Yönelik Ölçek Geliştirme Çalışması
}

DOI: $10.26466 /$ opus.691488

\begin{abstract}
Güler Karaman* - Hilal Çalışır** - Kübra Taş***
*Dr. Öğr. Üyesi, Atatürk Üniversitesi/Açıköğretim Fakültesi, , İ.̇̇.B.F, Erzurum /Türkiye

E-Posta: güler.karaman@atauni.edu.tr

ORCID: 0000-0001-5713-6759

**Doktora Öğrencisi, Atatürk Üniversitesi/Yönetim Bilişim Sistemleri, İ.̇̇.B.F, Erzurum /Türkiye E-Posta: clsrhilal@gmail.com

ORCID: $\quad$ 0000-0003-1090-1198

***Doktora Öğrencisi, Atatürk Üniversitesi/Yönetim Bilişim Sistemleri, , İ.İ.B.F, Erzurum /Türkiye

E-Posta: kubratas01@gmail.com

ORCID: 0000-0002-5929-5881

Öz

Günümüzde hızla gelişen teknoloji, Endüstri 4.0 olarak adlandırılan bir devrimi de beraberinde getirmiştir. Dördüncü sanayi devriminden sonra tamamen teknolojiyle uyumlu hale getirilen fabrikalarda daha donanımlı insan iş gücüne ihtiyaç duyulmuştur. Bu ihtiyaç ise eğitim de devrim niteliğinde sayılabilecek Ĕ̆̈itim 4.0'ı doğurmuştur. Öğretmenler Ĕ̆itim 4.0'ın en önemli tamamlayıcılarıdır. Bu sistemde öğretmen bilgi aktaran kişi olmasının yam sıra öğrenciye yeteneklerini keşfetme firsatı sunan, beceri kazandıran kişidir. Bu çalışmanın amacı öğretmenlerin eğitim 4.0'a karşı alğ ve tutumlarının belirlenmesine yönelik bir ölçeğin geliştirilmesidir. Çalışmada öğretmen adayları örneklem grubunu oluşturmaktadır. Bu ölçek geliştirme çalışmasına 150'si erkek, 214'ü kadın olmak üzere toplam 364 gönüllü öğretmen adayı katılmıştır. Çalışmada veriler hem çevrimiçi hem de basılı veri toplama formu ile toplanmıştır. Toplanan veriler SPSS 24.0 paket programı ile analiz edilmiştir. Geliştirilen ölçeğin geçerlilik ve güvenilirlik çalışmaları için ilk olarak verinin faktör analizine uygunlŭ̆u test edilmiş ve çıkan sonuca göre faktör analizi uygulanmıştır. Analizler sonucunda toplamda 6 faktör belirlenmiştir. Bu faktör analizi ışı̆̆ında her faktöre bağlantılı olan toplamda 38 maddeden oluşturulan ölçek ortaya koyulmuştur. Bu çalışma sonucunda eğitime yön veren öğretmen adaylarının bakış açısılyla Eğitim 4.0'ın önemi değerlendirilerek gelecekteki değişimlere ne derece uyum sağlayabileceklerine yönelik önerilerde bulunulmuştur.
\end{abstract}

Anahtar Kelimeler: Eğitim 4.0, Dijitalleşme, Dijital Eğitim, Endüstri 4.0 


\title{
Scale Development Study for Determining the Perceptions and Attitudes of Pre-Service Teachers towards Education 4.0
}

\begin{abstract}
Today, the rapidly developing technology carry with a revolution called Industry 4.0. After the fourth industrial revolution, more fully equipped manpower has been needed in the factories, which were fully dressed with technology. This need has also led to Education 4.0, which can be considered as a revolution in education. Teachers are the most important complement of Education 4.0. In this system, the teacher is the actor who transfers information as well as the actor who gives the student the opportunity to discover his talents and gains skills. The aim of this study is to develop a scale for determining the perceptions and attitudes of teachers towards Education 4.0. Pre-service teachers constitute the sample group in this study. A total of 364 pre-service teachers, including 150 men and 214 women, participated in this scale development study. Data were collected via both online and printed data collection form. The collected data were analyzed with SPSS 24.0 package program. For the validity and reliability studies of the developed scale, first the suitability of the data for factor analysis was tested and then factor analysis was applied according to the result obtained. As a result of the analyzes, a total of 6 factors were determined. In the light of this factor analysis, a scale consisting of 38 items in total, which is related to each factor, has been revealed. As a result of this study, the importance of Education 4.0 from the perspective of prospective teachers who guide education has been evaluated and suggestions have been made regarding how they can adapt to future changes.
\end{abstract}

Keywords: Education 4.0, Digitalization, Digital Education, Edustry 4.0 


\section{Giriş}

Değişen dünyada her gün yaşanan teknolojik gelişmeler dördüncü sanayi devrimini getirmiş ve 4. Sanayi devrimi Endüstri 4.0 olarak adlandırılmıştır (Lasi, Fettke, Kemper, Feld ve Hoffmann, 2014). Endüstri 4.0 endüstriyel süreçler ile bilişim teknolojilerini bir araya getirmeyi amaçlamaktadır. (Schuh, Potente, Wesch-Potente, Weber ve Prote, 2014)'e göre Endüstri 4.0 üretim süreçleri içerinde direkt ya da dolaylı olarak ilişkili olan, tüm birimlerde kullanılan en son teknolojileri internet aracılı̆̆ıyla eş zamanlı bir şekilde çalışmasını öngören düzenlemelerdir. İlk defa 2011 yılında Hannover Fuarı'nda Alman Eğitim ve Araştırma Bakanlığı tarafında Gelecek-Projeri'nden biri olarak bahsedilip önceki sanayi devrimlerine benzetilse de bu devrim içerisinde her alanı etkileyecek değişimleri barındırmaktadır (Eldem, 2017; Yalçınkaya, Korkmaz ve Karataş, 2019). Endüstri 4.0 bireylere yüksek standartlarda bir yaşam ve gelecek sunmayı amaçlamaktadır. Bu sebeple teknolojiye uyum sağlayan ve daha donanımlı insan iş gücüne ihtiyaç duyulmaktadır. Karataş (2017), Endüstri 4.0'ın eğitim, sanat, sağlık ekonomi gibi alanlarda da dönüşümü gerekli kıldığını söyleyerek salt teknoloji kullanımının ötesine gitmiştir ve Endüstri 4.0'ın gelişimine bağlı olarak eğitim sistemlerinde dijital bir dönüşüm yaşanması gerektiğine dolaylı olarak değinmiştir. Endüstri de yaşanan bu değişim endüstriyel gereksinimleri tamamlamak için yeni bir eğitim sistemine geçiş sürecini zorunlu kılmıştır. Endüstri 4.0'dan sonra "Eğitimle ilgili her şey, eğitim yöntemi, öğrenci ve öğretmen rolleri, eğitim araç ve gereçleri, eğitimin içeriği kaçınılmaz olarak değişmiştir." Bu değişim ve dönüşüm ise Eğitim 4.0 olarak adlandırılmıştır (Yalçınkaya vd., 2019). Eğitim 4.0; geleneksel ezber odaklı eğitim sistemlerinin aksine, teknolojiden yararlanan ve kişiye özel eğitim sistemi çerçevesinde günümüz dünyasının beklentilerini karşılayan deneyim temelli yeni bir eğitim sistemi olarak ifade edilmektedir (Yelkikalan, Ayhün, Aydın ve Kurt, 2019).

Endüstri 4.0 kavramı sanayi dışındaki daha geniş bilim dallarını içine alacak şekilde genişletilmeye başlanmış ve Eğitim 4.0 gibi kavramlar ortaya çıkmıştır ve farklı alanlarda nasıl etki bırakacağı üzerine çalışmalar başlatılmıştır (Abdelrazeq, Janssen, Tummel, Richert ve Jeschke, 2016). İncelenen Eğitim 4.0 ile ilgili farklı çalışmalarda alanyazın taraması yapılmış ve sonuç olarak, eğitim ve öğretimin Eğitim 4.0 çerçevesinde tekrar tanımlanması/değişmesi gerektiği saptanmıştır. Ayrıca bu değişim için bir model veya temel dönüşüm 
noktaları belirlenmiştir (Öztemel, 2018; Demir, 2018; Yelkikalan vd., 2019; Mourtzis D. , 2018; Puncreobutr, 2016; Prieto, Sobrino, Soto, Romero, Biosca ve Martınez, 2019; Chea ve Huan, 2019; Şener ve Elevli, 2017; Aberšek ve Flogie, 2017). Alan yazın taraması sonucu bulunan çalışmalar aşağıdaki gibidir:

Eğitim 4.0; öğreticiler açısından, nitel, nicel, literatür araştırması ve gözlemleme yöntemleriyle çalışılmıştır. Bu çalışmalarda ortak olarak, öğretmen ve öğretmen adaylarının eğitim 4.0 kavramını memnuniyetle karşıladıkları ve eğitim hayatına aktarılmasını destekledikleri sonucuna ulaşılmıştır (Hus$\sin$ 2018; Mourtzis, Vlachou, Dimitrakopoulos ve Zogopoulos, 2018; Goldie, 2016; Harkins 2008). Ayrıca Hussin (2018) daha güncel teknolojilerin eğitime entegre edilmesi, eğitmenlerin derslerini tasarlamada daha yaratıcı olmalarını ve bu şekilde öğrenmeyi daha ilginç hale getirmelerini sağlayacaklarını da belirtmişlerdir.

(Hussin 2018; Mourtzis vd., 2018; Eichinger, Hofig ve Richter 2017; Ciolacu, Tehrani, Beer ve Popp, 2017) tarafından yapılan çalışmada nitel, nicel ve deneyler yöntemiyle Eğitim 4.0 öğrenciler açısından incelenmiştir. İnceleme sonucu ortak olarak, öğrencilerin pozitif yönde dönüt verdiğine, daha hızlı ve daha erken öğrenme gösterdiğine, önlerine çıkabilecek sınavları kazanma ihtimallerinin arttı̆̆ına, iş bulma imkânlarının arttığına ve Endüstri 4.0'a uyum sağlayan mühendisler ve bireyler olarak mezun oldukları sonucuna ulaşılmıştır. Ayrıca Eichinger vd. (2017) çalışmalarında açıklanan yöntemlere dayanarak yeni laboratuvar, proje çalışmaları ve ders modülleri oluşturulabileceği ve halihazırda mevcut olan kurslara entegre edilebileceğini de belirtmişlerdir.

Avrupa Komisyonu'nun Haziran ayında yayımladığı Eğitim 4.0 adlı raporunda, öğretmelerin teknoloji ile nasıl eğitim yapılacağını öğretecek temel öğeleri olduğu ve dijital eğitim için eğitilmeleri gerektiği belirtilmiştir. Öğrenciler yarım gün, tam gün, mesleki her grup veya kültürden oldukları farketmeksizin Commissioan (2017) diyerek gelişen teknolojiye yetişebilmek için Eğitim 4.0’a öğretmen ve öğrencilerden başlanması gerektiğini belirtmişlerdir. Bu nedenle bu çalışma üniversite de okuyan öğretmen adaylarının eğitim 4.0'dan haberdar olup olmama durumları, alg1 ve tutumlarının ne yönde olduğu sorularına cevap verebilen bir ölçek geliştirmek için oluşturulmuştur. Bu doğrultuda karma bir yöntemin kullanıldığı çalışma gerçekleştirilmiştir. 
Çalışmaya 364 öğretmen adayı gönüllü katılım sağlamıştır. Geçerlilik ve güvenirlik analizleri yapılarak altı faktörden oluşan bir ölçek geliştirilmiştir.

\section{Araştırmanın Amacı ve Önemi}

Bu çalışmada, öğretmen adaylarının Eğitim 4.0'a karşı algı ve tutumlarının belirlenmesine yönelik bir ölçeğin geliştirilmesi amaçlanmıştır. Bu amaç doğrultusunda aşağıda belirlenen sorulara cevap aranmıştır.

\section{Araştırma soruları:}

1. 1.Ĕ̈itim $4.0^{\prime}$ a yönelik öğretmen adaylarının algı ve tutumlarını gösteren faktörler nelerdir?

2. Eğitim 4.0'a yönelik öğretmen adaylarının algı ve tutumlarını gösteren göstergeler nelerdir?

Bu çalışma, Eğitim 4.0 kavramının önemini öğretmen adaylarının bakış açlarıyla ayrıntılı bir şekilde ortaya koymasından dolayı alanyazına katkı getireceği düşünülmektedir. Öğrenme sürecinde Eğitim 4.0'a yönelik çalışmaların azlığı ve gerçekleştirilen çalışmanın karma yöntemle güçlendirilmesinden dolayı alanyazına katlı sağlayacağı düşünülmektedir.

\section{Yöntem}

Öğretmen adaylarının Eğitim 4.0'a karşı algı ve tutumlarının belirlenmesine yönelik bir ölçek geliştirmeye yönelen bu araştırmada, nitel ve nicel araştırma tekniklerinin bir arada bulunduğu karma yöntem kullanılmıştır. Karma yöntem, araştırmacının araştırma problemlerini anlamak için nitel (açık uçlu) ve nicel (kapalı uçlu) olmak üzere veri toplamada iki veri setinin bütünleşik kullanıldığı, Sosyal Bilimler, Sağlık Bilimleri, Davranış bilimleri vb. alanlarda kullanılan bir karma araştırma yaklaşımıdır (Greene, Krayder ve Mayer, 2005; Creswell, 2017). Nicel ve nitel veriler anket yöntemiyle elde edilen verilerle raporlanmıştır. Bu başlık altında çalışmanın evren ve örneklem, ölçeğin geliştirilme süreci, verilerin toplanması ve analiz aşamalarına yönelik bilgilere yer verilmiştir.

\section{Evren ve Örneklem}

Çalışmada örneklem seçim yöntemlerinden uygun örnekleme yöntemi esas alınarak örneklem oluşturulmuştur. Zamandan tasarruf edip iş gücü kaybını 
önlemek için uygun örnekleme yöntemi seçilmiştir (Büyüköztürk, Çakmak, Akgün, Karadeniz ve Demirel, 2010). Elde edilen sonuçların güvenilir olması için örneklem sayısı fazla tutulmaya çalışılmıştır. 150'si erkek, 214'ü kadın olmak üzere toplam 364 öğretmen adayından veri toplanmıştır. Çalışma 20192020 yılının güz döneminde gerçekleştirilmiştir. Örneklem grubu çalışmaya katılan gönüllü öğretmen adaylarından oluşmaktadır.

Çalışmaya en fazla katılım Okul Öncesi Öğretmenliği bölümü (75) iken en az katılım gösteren alanlar Özel Eğitim Öğretmenliği (1), Arapça Öğretmenliği(1), Fransızca Öğretmenliği(1) ve Müzik Öğretmenliği(1) bölümüdür.

En fazla katılım Atatürk Üniversitesi (319) iken en az katılım Kocaeli Üniversitesi(1), Tokat Gazi Osman Paşa Üniversitesi(1),Yozgat Bozok Üniversitesi(1), Trakya Üniversitesi(1), Süleyman Demirel Üniversitesi(1), Erzincan Binali Yıldırım Üniversitesi(1), Gaziantep Üniversitesi(1), Muğla Sıtkı Koçman Üniversitesi(1), Düzce Üniversitesi(1), Anadolu Üniversitesi(1), Bakü Devlet Üniversitesi(1), Ömer Halis Demir Üniversitesi(1), Kastamonu Üniversitesi(1) ve Amasya Üniversitesi(1) olmuştur.

\section{Ölçeğin Geliştirilme Süreci}

Ölçek geliştirme sürecinde alanyazındaki ölçekler ve kaynaklar "Eğitim 4.0, Uzaktan eğitim, Uzaktan eğitim algısı" anahtar kelimeleri ile incelenerek öğretmen adaylarının Eğitim 4.0’a karşı algı ve tutumları ile ilgili maddeler çıkarılmaya çalışılmıştır. "Google Akademik", "Ebsco" “Ulusal Tez Merkezi” ve "Scopus" veri tabanları üzerinden araştırılan konu ile ilgili bildiriler, makaleler ve tezler incelenmiştir. Alan yazın taramasının ardından 175 soruluk madde havuzu oluşturulmuştur. Madde havuzundan birbirini kapsayan sorular alan uzmanı ile birlikte çıkarılmış ve olmadığı düşünülen maddeler eklenmiştir. Bu süreç alan uzmanı ile yürütülmüştür. Süreç sonunda maddelerden oluşan form oluşturulmuştur. Formun başlı̆̆ 1 ve eklenmesi gereken açıklayıcı bilgilere bu aşamada karar verilmiş̧ir. Ardından yapılan ikinci sadeleştirme ile madde sayısı 63'e, üçüncü sadeleştirme ile de madde sayısı 59'a düşürülerek formun son hali oluşturulmuştur. Oluşturulan form ise dil uzmanı tarafından kontrol edilerek düzenlenmiştir. Maddelerin değerlendirilmesinde 5'li likert tipi ölçek kullanılmıştır (1=Kesinlikle Katılmıyorum, 2=Katılmiyorum, 3=Kararsızım, 4=Katılıyorum, 5=Kesinlikle Katılıyorum). Ölçekte yer alan maddelerin 53'ü olumlu, 5'i olumsuz ve bir soru ise açık uçlu soru 
olarak yer almıştır. Maddeler tesadüfilik esasına göre ölçekte sıralanmıştır. Ölçeğin başına ise demografik veriler içeren 12 maddeden oluşan bölüm eklenmiştir.

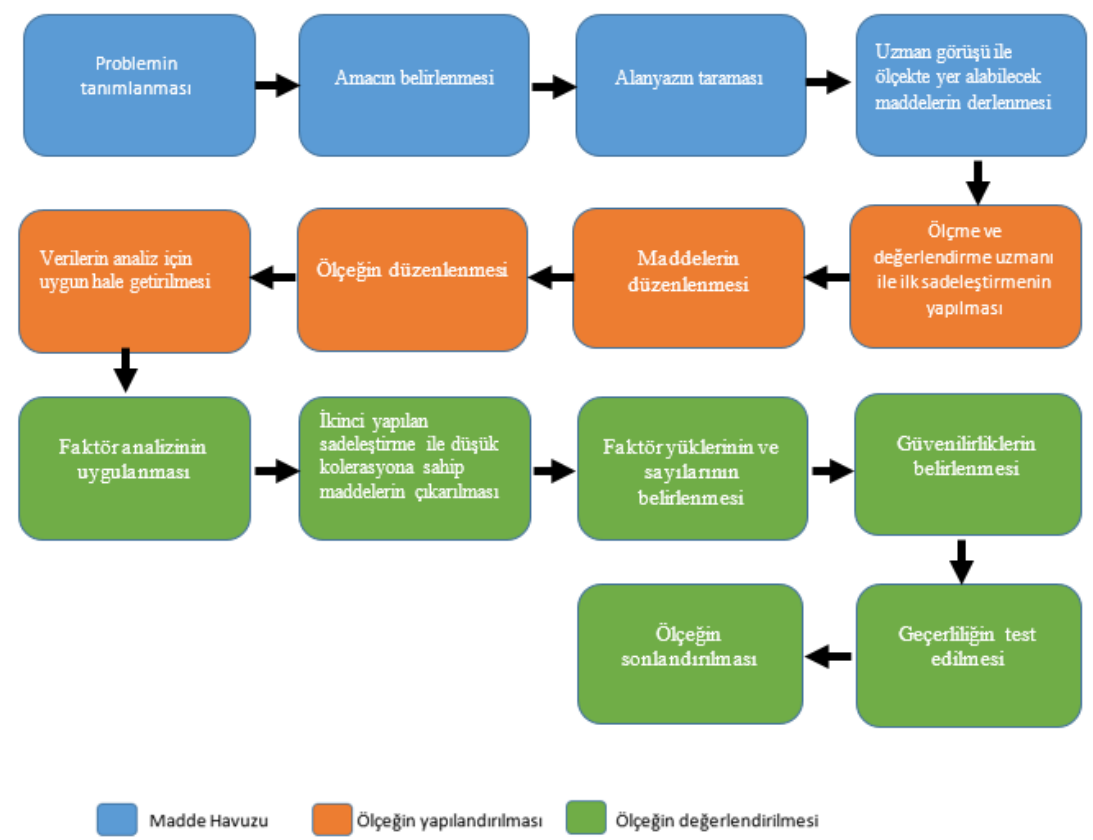

Şekil 1 Ölçek Geliştirme Süreç Aşamaları (Karaman, 2015)

\section{Verilerin Toplanması}

Öğretmen adaylarının Eğitim 4.0’a karşı algı ve tutumlarını tespit etmek için oluşturulan ölçek üç bölümden oluşmaktadır. Birinci bölümde katılımcıların demografik bilgileri yer almaktadır. Demografik bilgiler; cinsiyet, yaş, barındığ1 yer, mezun olduğu lise türü, ortalama kişisel gelir, AGNO, internete en çok erişilen araç, internette günlük ortalama harcanan zaman, okuduğu üniversite, okuduğu bölüm, Eğitim 4.0'dan haberdar olma durumu ve yeni teknolojileri takip etme sıklığı olmak üzere toplam 12 bağımsız değişkenden oluşmaktadır. İkinci bölümde öğretmen adaylarının eğitim 4.0' a karşı algı ve tutumlarını ölçmeye yönelik hazırlanan maddeler yer almaktadır. Son bölümde ise "Eğitim 4.0 nedir?" sorusu sorularak katılımcıların bu konudaki görüşü alınmıştır. Doktora seviyesi ölçme ve değerlendirme uzmanının gö- 
rüşünden sonra elde edilen formda açıklayıcı bilgi içeren bir metne yer verilmiştir. Oluşturulan anket ile hem kâğıt form ile hem de web sitesi üzerinden veri toplanmıştır. Web sitesi üzerinden mail ve WhatsApp uygulaması arac1ğıyla gönüllü katılımcılara ulaştırılarak 80 veriye ulaşılmıştır. Yeterli veri elde edilemeyince gönüllü katılımcılara tekrar hatırlatma amacıyla bilgilendirici form gönderilmiş ve ardından veri sayısı 165'e çıkarılmıştır. 215 veri ise kâğıt form üzerinden araştırmacılar tarafında toplanmıştır. Ölçeğin doldurulması ortalama 15-17 dakika sürmüştür. Veri toplama aracı olarak hazırlanan anket öğretmen adaylarına ulaştırılarak toplamda 380 tane cevaplandırılmıştır. Ankete verilen cevaplar incelendiğinde bazı öğretmen adaylarının anketi özensiz doldurmaları sebebiyle 16 tanesi geçersiz kılınarak değerlendirilmeye alınmamıştır. Veriler analiz edilmeden önce 5 tane olumsuz madde ters kodlanarak analize dâhil edilmiştir.

\section{Nicel Verilerin Analizi}

Öğretmen adaylarının Eğitim 4.0 hakkında algı ve tutumlarını belirlemesine yönelik ölçeği geliştirmek amacıyla toplanan anket verilerinin analizinde SPSS 24.0 paket programı kullanılmıştır. 364 öğrenciden toplanan veriler ile ölçeğin geçerlik ve güvenirlik çalışmaları gerçekleştirilmiştir.

Ölçeğin analiz sürecinde ilk adımında, anket formu ile toplanan verilerin faktör analizine uygun olup olmadığı Kaiser-Meyer-Olkin (KMO) katsayısı ve Barlett Sphericity testi ile kontrol edilmiştir (Bayram, 2004; Büyüköztürk, 2005). Ayrıca öğretmen adaylarının Eğitim 4.0 hakkında algı ve tutumlarını belirlemesine yönelik ölçeği oluştururken toplanan veriler betimsel istatistik sonuçları ve histogram grafiği incelenerek dağılım durumlarına göre incelenmiştir. Ardından araştırma kapsamında belirlenen araştırma sorula cevaplanmıştır. Son olarak da madde-etkileşim puanı korelasyonu, Spearman Brown iki yarı test korelasyonu ve Cronbach alfa iç tutarlılık katsayısı hesaplanmıştır. Geliştirilen ölçeğin uygulanmasında ise Atatürk Üniversitesi Eğitim Fakültesinde anket form üzerinden toplanan verilerin güvenilirlik, normallik, çarpıklık ve basıklık değerlerine bakılarak one-way anova testi uygulanmıştır.

\section{Nitel Verilerin Analizi}

Nitel araştırma, insanların davranışlarını, yaşam tarzlarını ve örgüt yapılarını anlamaya yönelik bir bilgi üretme sürecidir (Strauss ve Corbin, 1990). Nitel 
araştırma insanların olaylar karşısında öznel bakış açılarını keşfetmelerini, kendi sınırlarını çözmelerini ve toplumsal sistemin derinliklerini keşfetmelerini hedeflemektedir (Storey, 2007). Bu çalışmada nitel veri analiz türleri arasında sık kullanılan içerik analizi yöntemi kullanılmıştır. Bu amaçla görsel ve yazılı verilerin analiz edilmesinde kullanılmaktadır. İçerik analizi yönteminde tümden gelim yolu izlenmektedir. Araştırmacı ilk olarak kategoriler geliştirmekte ve sonrasında incelediği veri seti içinde geliştirdiği kategorilerin içerisine giren kelime veya resimler saymaktadır. Araştırmacı, konu üzerine çalışan diğer araştırmacıların da aynı sonuçlara ulaşabilecekleri türden kategoriler geliştirmelidir (Silverman, 2001).

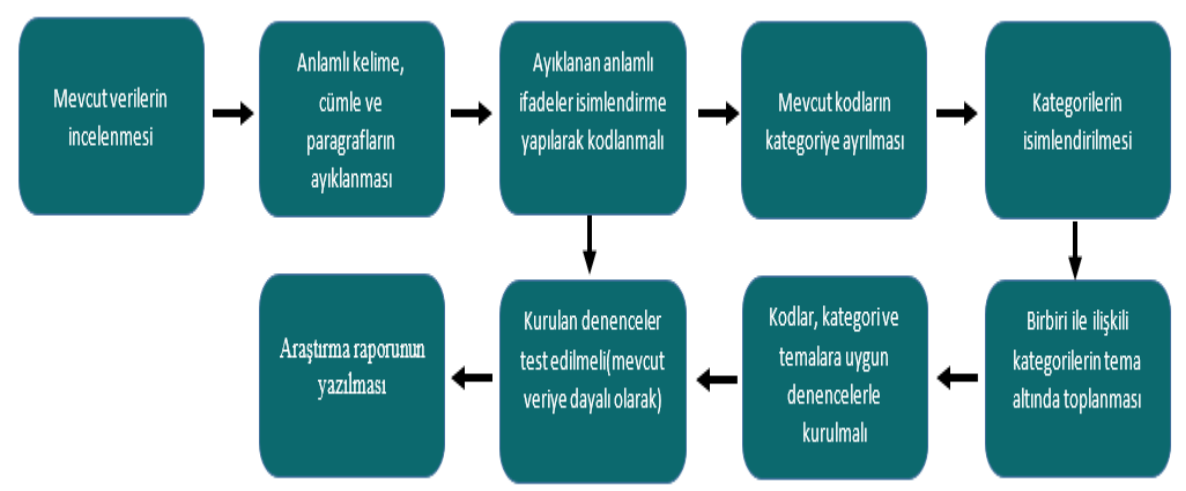

Şekil 2 Nitel Veri Analizi Aşamaları (Marshall Ve Rossman, 1995 Akt. (Ratcliff, 2008))

Anket yöntemi ile elde edilen nitel verilerin analizinde NVivo 12 paket programı kullanılmıştır. En çok tekrar eden kelimeler ile kelime bulutu oluşturulmuştur.

\section{Uygulama Çalışması}

Çalışma kapsamında geliştirilen anket Atatürk Üniversitesi Eğitim Fakültesinde okuyan öğretmen adayları üzerinde uygulanmıştır. Uygulamaya 84’ü erkek74'ü kadın olmak üzere toplamda 162 öğretmen adayı katılım sağlamıştır. Öğretmen adaylarından toplanan verilerin güvenilirliğinin ölçülmesi amaciyla SPSS 24.0 paket programı üzerinden Crobnbach's Alpha yöntemi kullanılmıştır. Katılımcıların Eğitim 4.0 hakkında algı ve tutumlarını ölçmek 
için “Öğretmen Adaylarının Eğitim 4.0’a Karşı Alg1 ve Tutum Belirleme Ölçeği" kullanılmıştır. Toplanan veriler SPSS 24.0 paket programı ile analiz edilmiştir. Analiz edilen verilerin normallik, çarpıklık ve basıklık değerlerine bakılarak, one-way anova testi uygulanmıştır.

\section{Araştırmacıların Rolï}

Araştırmacı kaynaklara ulaşma, kaynakları derleme, düzenleme, elde edilen verilerin geçerlilik ve güvenirlilik testlerini yapma, analiz etme ve yorumlama işlerini yerine getirmiştir. Yapılan karma çalışmada alanyazın incelemesi için ölçme ve değerlendirme uzmanı ile görüşülmüş, araştırmacı ve uzman ile ortak fikir yürütmeleri yapılarak veriler toplanmıştır. Nitel çalışma için elde edilen verilere içerik analizi yapılmış, verilerden kodlar ve temalar oluşturulmuştur. Verilerin güvenirliği uzman görüşü ile sağlanarak analiz edilecek veriler yorumlanmıştır. Nicel çalışmada ise verilerin form haline dönüştürülmesi, geçerlilik ve güvenirlilik analizlerinin yapılması uzman eşliğinde araştırmacı tarafından yapılmıştır.

\section{Bulgular}

\section{Öğretmen Adaylarının Ĕ̆itim 4.0'a Karşı Algı ve Tutumların Gösteren Göstergeler}

Bu bölümde öğretmen adalarının eğitim 4.0 kavramı hakkındaki bilgi düzeylerini belirlemeye yönelik bulgular verilmiştir. "Eğitim 4.0 nedir?" sorusuna verilen derlenmiştir. Yapılan nicel çalışma ile “Eğitim 4.0'ın Öğreticiye cevaplar Etkisi", "Eğitim 4.0’ın Öğrenime Etkisi", "Eğitim 4.0 Etkisi (Beklenen Fayda)", "Eğitim 4.0 Algısı", "Eğitim 4.0'ın Uygulanabilirliği" ve "Eğitim 4.0'ın Sosyalleşme Etkisi" faktörlerinden oluşan başlıklar ortaya çıkmıştır. Yapılan nitel çalışmadan elde edilen verilerle nicel çalışmanın faktörlerini destekleyen başlıklar oluşturulmuştur.

\section{Eğitim 4.0'ın Öğreticiye Etkisi}

Eğitim 4.0'ın öğreticiye pek çok etkisi olduğu söylenebilmektedir. Derslerin hem uygulamalı hem de teknolojiden yararlanarak yapılması ögretmenlerin dersleri anlatırken yaşadığı zorlukları ortadan kaldırabilir ya da karşılaşma- 
dığı zorlukları ortaya çıkarabilir. Öğretmen adayları ile yapılan görüşme sonucunda Eğitim 4.0'ın öğreticiye etkisi ile ilgili görüşlerine aşağıda yer verilmiştir:

“...Geleneksel eğitimde olduğu gibi düz anlatım ile değil de öğrencinin aklında daha kalıcı bir iz bırakmak için görsel öğeler, oyunlar, grafikler vb. şeyler kullanılır. Bu da öğrencinin derse olan ilgisini arttırır. Teknolojik öğelerden yararlanıldı̆̆ $ı$ için kısa sürede öğrenciye birçok şey aktarllabilir. Örnek verecek olursam, teknolojik öğelerden yararlanarak kısıtlı bir sürede öğrencilere birden fazla örnek gösterilebilir..."

“...Ĕ̈itim 4.0, geleneksel eğitimin yerine dijitalleşerek, bireysel öğrenme hızına uygun ortam hazırlamaktır. Bu sayede eğitim ortamı daha etkili ve verimli hale gelir. Öğretmenlerin yükü hafifler öğrencilere ise firsat eşitliği să̆lar ve öğrenciye öğrendiği bilgileri gerçek yaşamda uygulama firsatı să̆lar..."

Öğretmenler adayları, derslerin daha fazla örnekle daha anlaşılabilir anlatılabilmesinin öğretmenlere yardımcı olacağını, Eğitim 4.0 ile gelen yeniliklerin öğretmenlerin yüklerini azaltacağını belirtmişlerdir.

\section{Ĕ̆itim 4.0'ın Öğrenime Etkisi}

Eğitim 4.0'ın öğrenciye, öğretmene ve öğrenime etki ettiği kolaylıkla söylenebilmektedir. Eğitim 4.0'ın sunmuş olduğu bireysel öğrenme gibi olanaklar eğitimde fırsat eşitliği sağlayabilmektedir. Öğretmen adayları ile yapılan görüşmede adayların Eğitim 4.0'ın getirdiği yeniliklerin öğrenime etkisi ile ilgili görüşlerine aşağıda yer verilmiştir.

“...Eğitim 4.0 eğitimle teknolojinin iç içe olmasıdır. Sürekli öğrenmeyi sağlayan bir sistemdir. İstediğin anda veya zamanda kullanılabilir olması ön plana çıkarıyor. Bireysel olarak algıladığım bu sistemi, daha çok düşünmeye ve düşündürmeye dayal, kişisel gelişim için oldukça önemli bir sistem olarak görüyorum. Daha çok uygulamaya dayalı bir sistem olması verilen eğitimin kalıcı olmasını sağlayacaktır..."

“...Ö̆̆grencilerin eğitim alanında kendi başarı ve bilgi düzeyinde ilerlemesini sağlayacak her birey özeldir ve biriciktir ilkesiyle adım atılmasını uygulamaya çalışan eğitim sistemidir ..."

Öğretmen adayları Eğitim 4.0'ın öğrenime zaman ve mekan bağımsızlı̆̆ kazandırdığını, düşünmeye ve düşündürmeye dayalı bir sistem olduğunu, kişinin bilgi ve becerisine dayanarak kişisel eğitim sunduğunu belirtmişlerdir. 


\section{Eğitim 4.0 Etkisi (Beklenen Fayda)}

Eğitim 4.0 teknoloji bazlı bir sistem olarak karşımıza çıkmaktadır. Eğitime yenilik getirmesiyle birlikte Eğitim 4.0'dan öğretim hayatını kolaylaştıracak çeşitli faydalar beklenmektedir. Öğretmen adayları ile yapılan görüşme sonucunda Eğitim 4.0'dan beklenen fayda ile ilgili görüşlerine aşağıda yer verilmiştir.

“...Bilgiye ulaşmayı ve uygulamayı kolaylaştıran bir teknoloji odakl sistemdir. Eğitim 4.0 ile teknolojiyi, bilgiyi ve bilgiye ulaşmayı bilinçli bir şekilde kullanabilirsek insan hayatına kazandıracağı en mükemmel sistemlerden bir tanesi olacaktır. Internet erişimi için sorun yaşamayan ortamlarda sağllklı sonuçlar elde edilebilir..."

“...Kişiye özel eğitim ile yeni dünyanm ihtiyaçlarna yant veren, ezbere dayah sistemin yerine dijital teknolojilerden faydalanan deneyim temelli yeni eăitim sistemidir..."

“... Eğitim 4.0, İnternet odakh eğitim sistemidir. Eğitim 4.0 ile öğretmen ya uzak eğitim şeklinde dersleri anlatacak ve internet üzerinden çeşitli materyaller sağlayacak ya da öğretmen teknolojiyi simıfin süzgecinden geçirerek geleneksel yöntemden uzak tamamen teknoloji odaklı bir eğitim sunacaktır..."

Öğretmen adayları Eğitim 4.0 ile teknolojiyi bilinçli bir şekilde kullanmanın insan hayatına fayda sağlayacağını, kişiye özel eğitim sunarak ihtiyaçlarını gidereceklerini ifade etmişlerdir.

\section{Ĕ̆itim 4.0 Algısı}

Eğitim 4.0 endüstri 4.0 ile beraber hayatımıza giren bir kavram ve sistem olduğu için toplum ve öğrenmenin temel taşı olan öğretmenlerde farklı algılar oluşturabilmektedir. Öğretmen adayları ile yapılan görüşme sonucunda Eğitim 4.0'ın algılanması ile ilgili görüşlerine aşağıda yer verilmiştir.

“...Eğitim 4.0, ezber yerine deneyimle öğrenmeyi hedefleyen alternatif öğretim şeklidir..."

“...Eğitim 4.0, öğrencilerin daha etkili öğrenmesini sağlayan firsat eşitliğini yaratan bir sistemdir..."

Öğretmen adayları Eğitim 4.0'ın geleneksel ezber sistemi yerine deneyim temelli öğrenme süreci olduğunu ve bireylerin öğrenme süreçlerinde firsat eşitliği sunduğunu ifade etmişlerdir. 


\section{Ĕ̆itim 4.0'ın Uygulanabilirliği}

Eğitim 4.0 ile gelen yenilikler eski öğretim ve öğrenim anlayışı ile zıt düşebilmektedir. Bu durum Eğitim 4.0'ın eğitim hayatında uygulanabilirliğini sorgulatabilmektedir. Öğretmen adayları ile yapılan görüşme sonucunda Eğitim 4.0'ın uygulanabilirliği etkisi ile ilgili görüşlerine aşağıda yer verilmiştir.

“...Eğitimin teorikten çok uygulamah olarak verilmesidir. Eğitimde geleneksel olan ezberleme yöntemiyle değil de, yeni ve gelişmiş programlarn eğitime sunulmasıdır. Bu eğitimin öğrenciler açısından faydalı olduğunu düşünüyorum..." dir..."

“...Eğitim 4.0, Ezbere dayalı sistem yerine, pratiğe ve uygulamaya dayah sistem-

“...Gelişen dünyaya ayak uydurarak teknolojinin etkisiyle eğitimi uygulayarak eğitim ortamına katılıma yardımcı olan öğrenci merkezli bir eğitimdir. Öğretmenlerin ve öğrencilerin bilgilere daha kolay ulaşmalarm ve dijitalleşen dünyanın gerisinde kalmamalarmı sağlar..."

Öğretmen adayları Eğitim 4.0 ile sunulan eğitimin teorikten ziyade uygulamalı ve pratiğe dayalı olduğunu, gelişmiş öğretim programlarına yer verildiğini ve bilgiye ulaşmanın daha kolay olduğunu ifade etmişlerdir.

\section{Eğitim 4.0'ın Sosyalleşme Etkisi}

Eğitim 4.0 teknoloji temelli bir sistem olduğundan fayda sağlamanın yanı sıra olumsuz yönleri de bulunabilmektedir. Teknoloji kullanımının bireyleri sosyal hayatın ve sosyalleşmenin dışında bıraktığı birçok araştırmacı tarafından söylenmiştir. Öğretmen adayları ile yapılan görüşme sonucunda Eğitim 4.0'ın sosyalleşmeye etkisi ile ilgili bir görüşe aşağıda yer verilmiştir.

“...Eğitim 4.0 eğitimi kişiye özel olması öğrencilerin daha iyi bir eğitim almasın sağlar. Ĕger bu sistem ile öğrencilerle özel olarak ilgilenilirse daha verimli ve adil eğgitim ortamı olacağını düşünüyorum. Eğitim 4.0 eğitiminin teknolojiye dayah olması, öğrenciler için kahıı öğrenme sağlayabilir ama teknolojiye olan bağımlılı̆̆ı arttıracağını düşünüuyorum. Eğitim 4.0'ın bir yandan yararlı olacağım diğer yandan teknolojiye olan bağımlılı̆̆m artmasından dolayı zararlı olabileceğini düşünüyorum. Ama öğrencilerin kendine has yeteneklerinin ortaya çıkacağını, özgüvenini arttıracağını ve bilgilerin daha kahıı olabileceğini düşünüyorum..."

Öğretmen adayları Eğitim 4.0'ın teknolojiye dayalı olmasının daha adil ve daha kalıc bir öğrenme ortamı sağlayacağı gibi yararlı yanlarının olmasının 
yanı sıra zararına da vurgu yapmıştır. Teknolojiye bağımlılığını arttırabileceğini ifade etmiştir.

\section{Kelime Bulutu}

Yapılan analizler sonucunda kelime bulutu oluşturulmuştur. Şekil 3'te kelime bulutu gösterilmiştir.

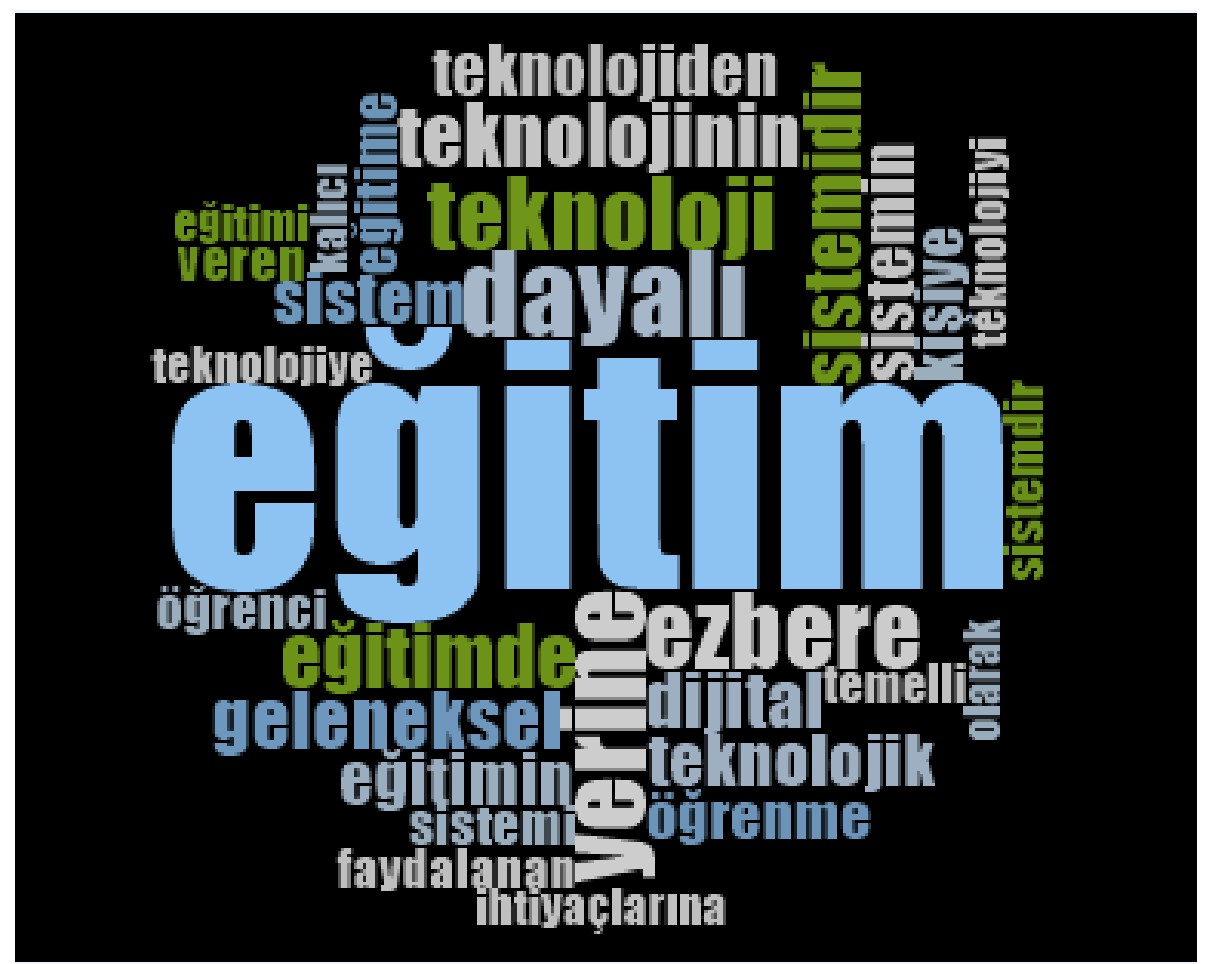

Şekil 3. Kelime Bulutu

Şekil 3'te yer alan kelime bulutu incelendiğinde öğretmen adaylarının Eğitim 4.0 algilarında en fazla etkili olan kavramların kelime bulutunun ortasında büyük puntolarla yazılmış eğitim, teknoloji, sistem, dijital, öğrenci, öğrenme, fayda, ihtiyaç kelimeleri oldukları görülmektedir. Resmin ortasında yer alan büyük punto en sık kullanılan kelimeleri, küçük punto ile yazılmış kelime ise daha az kullanılan kelimeyi göstermektedir. Kelime kullanım sıklığı bu aralıkta değişmektedir. Kelime bulutu oluşturulurken ile, ne, gibi veya vs. gibi 
bağlaçlar hariç tutulmuştur. Kelime bulutunda En çok kullanılan kelimeler birbirleri ile en çok ilişkili olan kelimelerdir.

\section{Öğretmen Adaylarının Ĕ̆itim 4.0 hakkında ki Algı ve Tutumunu Belirlemek için Geliştirilen Ölçeğin Geçerlilik ve Güvenilirlik Analizi}

Verilerin Faktör Analizine Uygunluğu: Yapılan Açımlayıc Faktör Analizi(AFA) sonucunda KMO analizi 0-1 arasında değerler alabilmektedir. Bu çalışmada toplanan verilerin faktör analizi için uygunluğunun test edilmesi amaciyla Kaiser-Meyer-Olkin (KMO) katsayısı ve Barlett Sphericity analizleri anlamlı çıkmıştır. Yani verilerin faktör analizi için uygun olduğu (KMO katsayısı \% 95,9 $(0,959>0,60)$ ve Barlet testi için anlamlılık $=0.000 \mathrm{p}<0,001)$ tespit edilmiştir. Çalışmadaki korelasyon katsayıları 1'e yaklaştıkça toplanan veri setinin faktör analizine uygun olması ve 0.60 üzeri değerlerin kabul edileceği (Büyüköztürk, 2005); göz önünde bulundurulduğunda, ulaşılan KMO katsayısının son derece yüksek bir değer olduğu görülmektedir.

Ölçek verilerinin faktör analizi için uygun çıkması üzerine, Eğitim 4.0 Alg1 ve Tutum Ölçeğinin yapı geçerliğini ve faktör yapısını incelemek amacıyla açımlayıcı faktör analizi ve faktörleştirme tekniği olarak ise temel bileşenler analizi kullanılmıştır. Yapılan analizlerde faktörlerin her değişken üzerindeki ortak faktör varyansı, maddelerin faktör yükleri, açklanan varyans oranları ve çizgi grafiği incelenmiştir. Daha sonrasında Croanbach Alfa ve Spearman Brown testi ile geliştirilen ölçeklerin güvenilirlikleri test edilmiştir.

Bu çalışmada öncelikle ölçekte yer alan maddelerin aralarındaki ilişkileri incelenmiştir. Faktörlerin tanımlaması için değişkenlerin arasındaki ilişkilerin korelasyonları belirlenmeli ve değişken grubunun birbiriyle ilişkili olması gerekmektedir. İlişki olmayan faktörler zorluk oluşturacağı için çıkarılmalıdırlar (Hutcheson ve Sofroniou, 1999). Bu yüzden korelasyon analizi sonucu katsayıları düşük olan değişkenler analizden çıkarılmıştır. Bu çalışmada maddeler için en düşük değer katsayısı 0,30 olarak belirlenmiştir (Hutcheson ve Sofroniou, 1999). Ayrıca bu çalışmada Büyüköztürk (2006) çalışmasında yer aldığı gibi, tek bir faktörde yüksek yük değerine, diğer faktörlerde ise düşük yük değerine sahip olması ve yüksek iki yük değeri arasındaki farkının en az 0,1 olması dikkate alınmıştır. Çalışmada ilk olarak literatür çalışması sonucunda 57 farklı anket sorusu belirlenmiş ve bu maddelerin korelasyon katsayıları hesaplanmıştır. Analiz sonucunda ortaya çıkan değerlerin hiç biri 
0,30'dan küçük değildir. Fakat faktör yükleri birden fazla faktöre dağılmış ve aralarındaki fark $0,1^{\prime}$ den küçük olan sorular çıkarılmıştır. Bu işlem 4 kere tekrarlanmıştır. Çıkarılan sorular aşağıda ki Tablo 1'te yer almaktadır;

Tablo 1 Açımlayıcı Faktör Analizi Sonucu Çıkarılan Anket Soruları

\begin{tabular}{cll}
\hline Aşamalar & & \multicolumn{1}{c}{ Çıkarılan Sorular } \\
\hline $\mathbf{1 .}$ & Aşamada & $53,37,27,34,38,58,10,56$ \\
\hline $\mathbf{2}$. & Aşamada & $28,31,35,40,39,30,29,9,1$ \\
\hline 3. & Aşamada & 32,26 \\
\hline 4. & Aşamada & 25 \\
\hline
\end{tabular}

Bunun ardından ölçeğe son şekil verilerek 38 likert tipi madde içeren ölçeğe öğretmen adaylarının algısını ve tutumunu ölçmede kullanılmak amacyyla son şekli verilmiştir. Tabloda 2'te ölçeğin 57 maddeli ve 38 maddeli halinde hesaplanan KMO ve Barlett test sonuçları yer almaktadır.

Tablo 2 KMO ve Bartlett's Testi Değerleri

\begin{tabular}{|c|c|}
\hline 57 madde ile elde edilen & \\
\hline Kaiser-Meyer-Olkin Measure of Sampling Adequacy & 0,959 \\
\hline Bartlett's Test of Sphericity Approx. Chi-Square & 13102,755 \\
\hline Df & 1596 \\
\hline Sig. & ,000 \\
\hline 38 madde ile elde edilen & \\
\hline Kaiser-Meyer-Olkin Measure of Sampling Adequacy & 0,944 \\
\hline Bartlett's Test of Sphericity Approx. Chi-Square & 7226,728 \\
\hline Df & 741 \\
\hline Sig. & ,000 \\
\hline
\end{tabular}

57 maddenin yer aldığı anket formu üzerinde analiz yapıldığında KMO test değeri 0,959, Barlett test değeri ise 13102,755 olarak bulunmuş ve sig. değeri anlamlı çımıştır. 38 maddenin yer aldığı anket formu üzerinde analiz yapıldığında KMO test değeri 0,944, Barlett test değeri ise 7226,728 olarak bulunmuş ve sig. değeri anlamlı çkmıştır.

\section{Öğretmen Adaylarının Eğitim 4.0'a Karşı Algı ve Tutum Belirleme Ölçeği'ne İlişkin Faktör Analizi Sonuçlarn}

Yapılan analizler sonucu geliştirilen Eğitim 4.0 algı ve tutum ölçeğinin faktör ve analizi sonuçları Tablo 3'te verilmiştir. 
Tablo 3 Faktör Analizi ile Açıklanan Toplam Varyans

\begin{tabular}{lllllll}
\hline Maddeler & \multicolumn{7}{c}{ Öz değerler } & \multicolumn{2}{c}{$\begin{array}{c}\text { Döndürülmüş } \\
\text { Yüklerin Toplamı }\end{array}$} & Kareli \\
\hline & Toplam & Varyans $\%$ & Kümülatif \% & Toplam & Varyans \% & Kümülatif \% \\
\hline 1 & 14,076 & 36,092 & 36,092 & 14,076 & 36,092 & 36,092 \\
2 & 2,324 & 5,958 & 42,050 & 2,324 & 5,958 & 42,050 \\
3 & 1,956 & 5,015 & 47,065 & 1,956 & 5,015 & 47,065 \\
4 & 1,536 & 3,939 & 51,005 & 1,536 & 3,939 & 51,005 \\
5 & 1,147 & 2,940 & 53,945 & 1,147 & 2,940 & 53,945 \\
6 & 1,012 & 2,594 & 56,539 & 1,012 & 2,594 & 56,539 \\
7 &, 962 & 2,467 & 59,005 & & & \\
8 &, 903 & 2,315 & 61,320 & & & \\
9 &, 879 & 2,254 & 63,575 & & & \\
10 &, 839 & 2,151 & 65,725 & & & \\
11 &, 797 & 2,044 & 67,770 & & & \\
12 &, 774 & 1,984 & 69,753 & & & \\
13 &, 739 & 1,896 & 71,649 & & & \\
14 &, 696 & 1,786 & 73,435 & & & \\
15 &, 678 & 1,738 & 75,173 & & & \\
\hline
\end{tabular}

Tablo 3 incelendiğinde, üzerinde analiz yapılan 38 likert tipi maddenin özdeğeri 1'den büyük olan 6 faktör altında toplandığ görülmektedir. Birinci faktörün tek başına toplam varyansın \% 36,092'sini açıkladığı, ikinci faktörün tek başına toplam varyansın \% 5,958'ini, üçüncü faktörün tek başına toplam varyansın \% 5,015'sını, dördüncü faktörün tek başına toplam varyansın \% 3,939'ini açıladığı, beşinci faktörün tek başına toplam varyansın \% 2,940'ını ve altınc faktörün tek başına toplam varyansın \% 2,594'ünü açkladığı tespit edilmiştir. Bu 6 faktörün ölçeğe ilişkin açıkladıkları toplam varyansın ise \% 56,539 olduğu görülmektedir.

Tablo 4 Maddelerin Faktör Dağılımı

\begin{tabular}{|c|c|c|c|c|c|c|}
\hline \multicolumn{7}{|c|}{ Faktörler } \\
\hline & 1 & 2 & 3 & 4 & 5 & 6 \\
\hline s50 & ,727 & & & & & \\
\hline s51 & ,724 & & & & & \\
\hline s55 & ,716 & & & & & \\
\hline $\mathrm{s} 42$ & ,694 & & & & & \\
\hline $\mathrm{s} 47$ & ,685 & & & & & \\
\hline $\mathrm{s} 45$ & 680 & & & & & \\
\hline s54 & ,668 & & & & & \\
\hline $\mathrm{s} 48$ & ,665 & & & & & \\
\hline s43 & ,659 & & & & & \\
\hline s44 & 650 & & & & & \\
\hline s49 & ,643 & & & & & \\
\hline s46 & 622 & & & & & \\
\hline
\end{tabular}




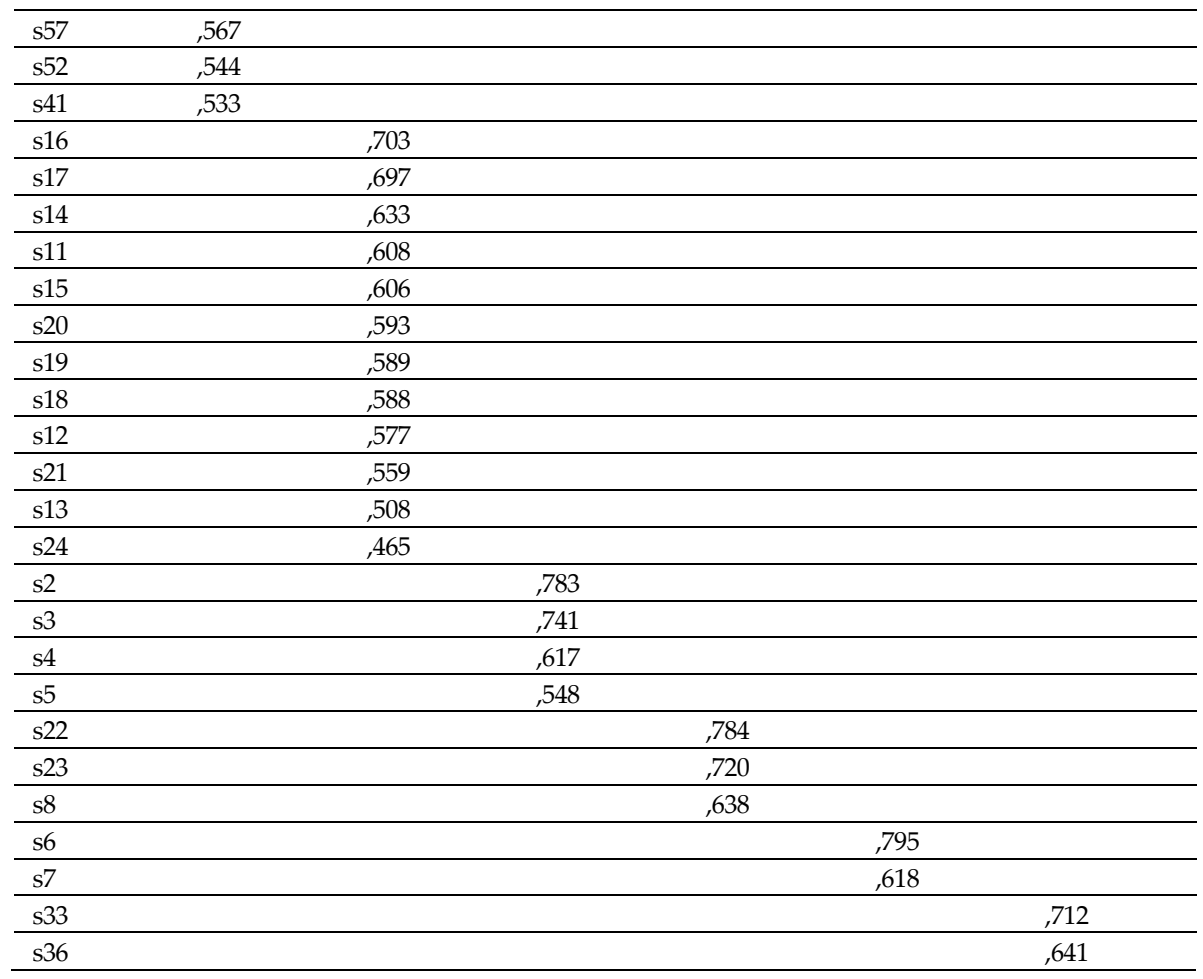

Öğretmen Adaylarının Eğitim 4.0 Hakkında Algı ve Tutum Belirleme Formunda yer alan 50., 51., 55., 42., 47., 45., 54., 48., 43., 44., 49., 46., 57., 52. ve 41. maddelerin birinci faktörü, 16., 17., 14., 11., 15., 20., 19., 18., 12., 21., 13. ve 24 . maddelerin ikinci faktörü, 2., 3., 4. ve 5. maddelerin üçüncü faktörü22., 23. ve 8. maddelerin dördüncü faktörü, 6 . ve 7. Maddelerin beşinci faktörü ve 33. Ve 36. faktörün ise altınc faktörü oluşturdukları Tablo 4 'te görülmektedir.

Tablo 4 'te gösterildiği gibi birinci faktörde yer alan maddelerin faktördeki yük değerleri 0,533 ile 0,727, ikinci faktörde 0,703 ile 0,465 , üçüncü faktörde 0,783 ile 0,548 arasında, dördüncü faktörde 0,784 ile 0,638 , beşinci faktörde 0,795 ile 618, altıncı faktörde ise 0,712 ile 0,641 arasındadır. Ayrıca Şekil 4'te gösterildiği gibi faktörlere ait çizgi grafiği incelenmiş ve altınc faktörden itibaren çizgi grafiğinin eğimini önemli ölçüde kaybetmeye başladığı görülmüştür. Bu nedenle faktör sayısı altı olarak belirlenmiştir. 


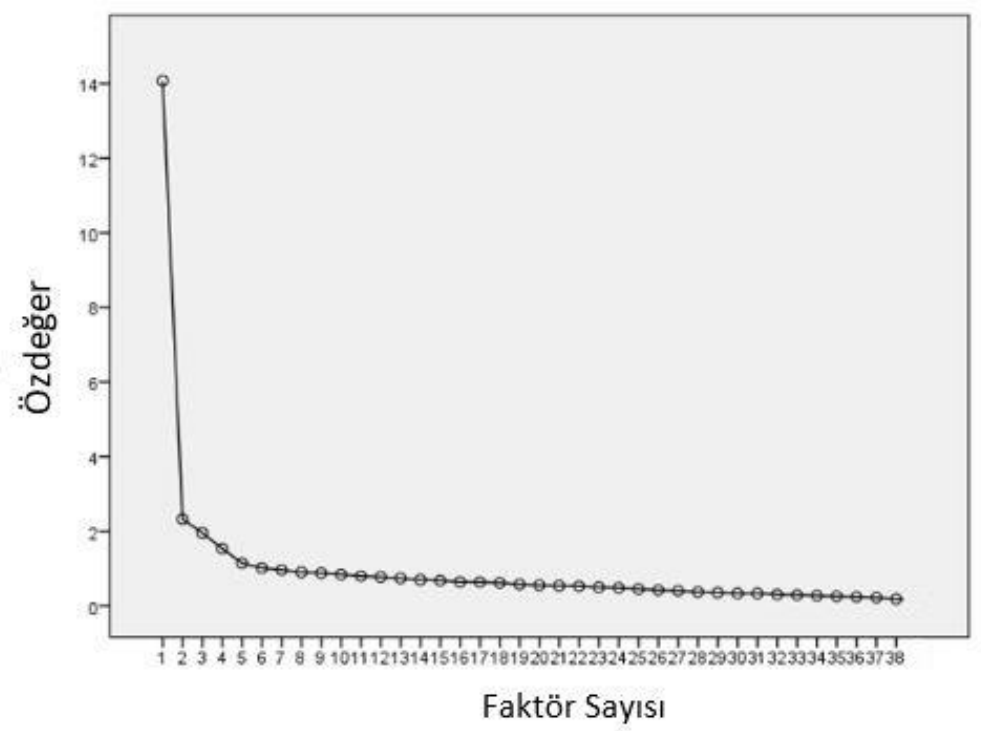

Şekil 4 Faktörlere Ait Çizgi Grafiği

Ĕ̆itim 4.0'a Yönelik Öğretmen Adaylarnın Algı ve Tutumların Gösteren Faktörler Nelerdir?

Maddelerin içerikleri ve içeriklerin aralarındaki ilişkiler incelendiğinde anket formu görsel olarak düzenlenmiştir. Ölçek maddelerinin faktörleri ile ilişkileri doğrultusunda altı faktör ortaya çıkmıştır. Bunlar birinci faktör "Eğitim 4.0'ın Öğreticiye Etkisi”, ikinci faktör "Eğitim 4.0'ın Öğrenime Etkisi", üçüncü faktör "Eğitim 4.0 Etkisi(Beklenen Fayda)", dördüncü faktör "Eğitim 4.0 Algısı", beşinci faktör “Eğitim 4.0' ın Uygulanabilirliği" ve altınc faktör ise “Eğitim 4.0'ın Sosyalleşme Etkisi"dir. Tablo 5'te gösterilmektedir.

Tablo 5 Eğitim 4.0 Hakkında Öğretmen Adaylarnın Algı ve Tutumlarına Yönelik Belirlenen Faktörler

\begin{tabular}{|c|c|}
\hline $\begin{array}{l}\text { Faktör } \\
\text { No }\end{array}$ & Belirlenen Faktör Başlıkları \\
\hline 1 & Eğitim 4.0'ın Öğreticiye Etkisi \\
\hline 2 & Eğitim 4.0'ın Öğrenime Etkisi \\
\hline 3 & Eğitim 4.0 Etkisi(Beklenen Fayda) \\
\hline 4 & Eğitim 4.0 Algısı \\
\hline 5 & Eğitim 4.0'ın Uygulanabilirliği \\
\hline 6 & Eğitim 4.0'ın Sosyalleşme Etkisi \\
\hline
\end{tabular}




\section{Eğitim 4.0 Kavramına Yönelik Öğretmen Adaylarnı Algı ve Tutumlarmı Et- kileyen Göstergeler Nelerdir?}

Yukarı da anlatıldığı gibi yapılan çalışmada ölçek geliştirilmesi amacıyla literatür taraması sonucu madde havuzundan uzmanlar tarafından seçilerek oluşturulan form soruları faktör analizi sonucu Tablo 6'da gösterildiği gibi faktörlere ve her faktöre ait göstergelere ayrılmıştır.

Tablo 6 Ĕ̆itim 4.0 Kavramı Hakkında Öğretmen Adaylarının Algı ve Tutumlarına Yönelik Göstergeler

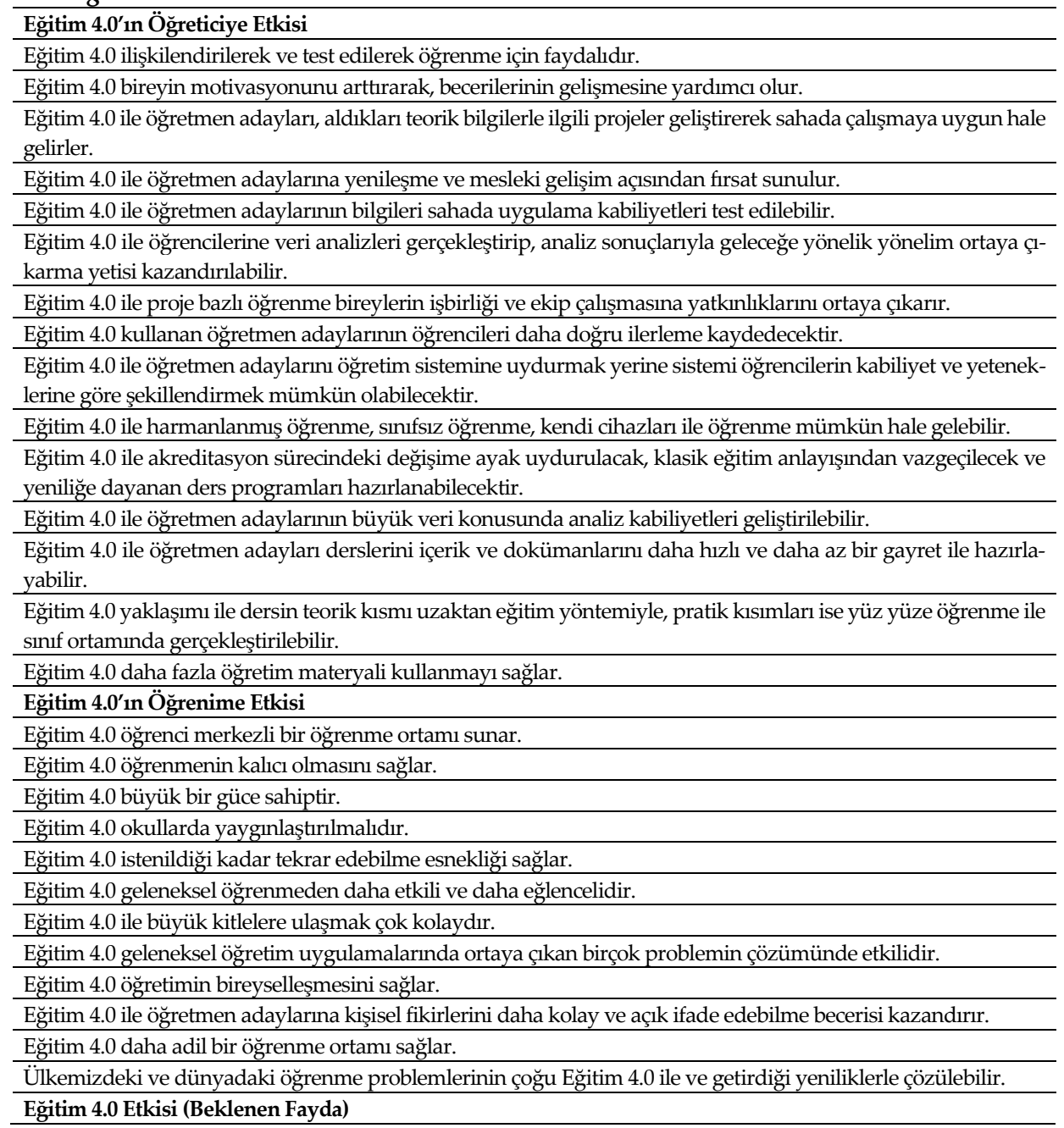




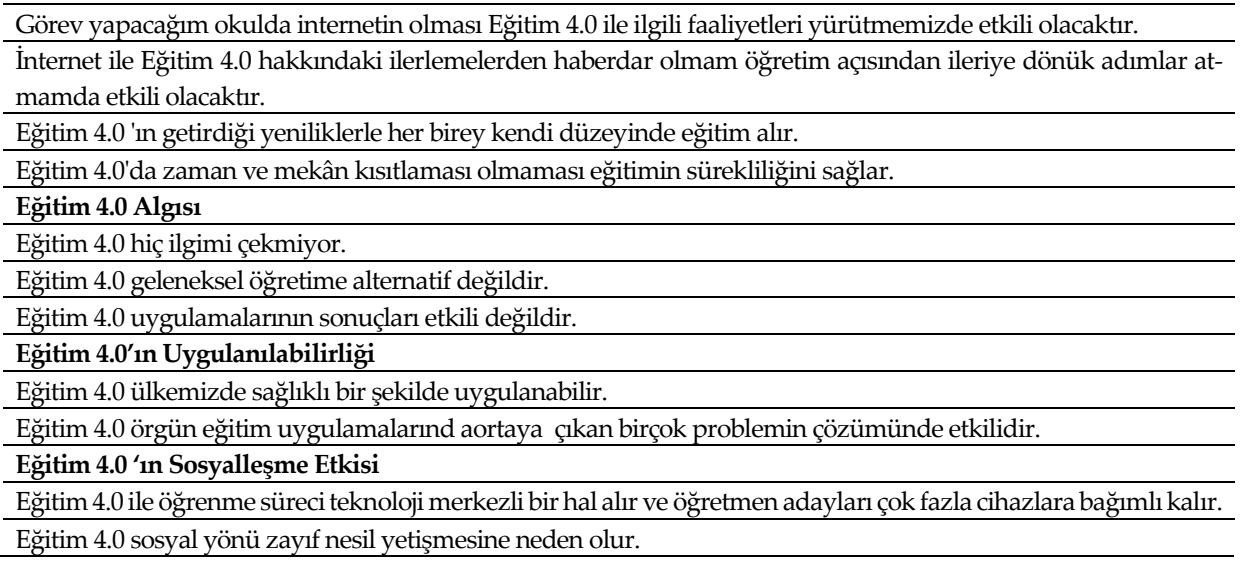

\section{Öğretmen Adaylarının Ĕ̆itim 4.0'a Karşı Algı ve Tutumlarını Belirleme Ölçeği Güvenilirliği}

Öğretmen Adaylarının Eğitim 4.0 Hakkında Ki Algı ve Tutumu Belirleme formunun güvenilirlikeri iki yolla analiz edilmiştir. Illk olarak Cronbach alfa iç tutarlılık katsayısı hesaplanmış ve 0,948 bulunmuştur. Sonrasında test yarılama yöntemiyle geliştirilen ölçeğin güvenilirliği test edilmiş ve Spearman Brown iki yarı test korelasyonu 0,836 olarak bulunmuştur.

Geliştirilen ölçeğin güvenilirliğine dair elde edilen kanıtlar "Öğretmen Adaylarının Eğitim 4.0'a Karşı Algı ve Tutumlarını Belirleme Ölçeği” formunun öğretmen adaylarının eğitim 4.0 hakkındaki algı ve tutumlarını belirlemede güvenle kullanılabileceğini göstermektedir.

\section{Tartışma Ve Sonuç}

$\mathrm{Bu}$ çalışma kapsamında öğretmen adaylarının eğitim 4.0'a karşı algı ve tutumlarının belirlenmesine yönelik bir ölçek geliştirilmiştir. Ölçek "Eğitim 4.0’ın Öğreticiye Etkisi”, "Eğitim 4.0’ın Öğrenime Etkisi”, "Eğitim 4.0 Etkisi (Beklenen Fayda)", "Eğitim 4.0 Algısı", “Eğitim 4.0'ın Uygulanabilirliği” ve "Eğitim 4.0' in Sosyalleşme Etkisi" olmak üzere yapılan nicel analizlerle altı faktör altında toplanmıştır. Yapıla nitel çalışma bulgularıyla bu altı faktörü destekler nitelikte sonuçlar elde edilmiştir.

Analiz sonuçlarıyla geliştirilen anket formu dikkate alındığında öğretmen adaylarının Eğitim 4.0'1 destekledikleri ve eğitim sisteminin ölçekte belirlenen sinurlar çerçevesinde tekrar düzenlenmesi gerektiği konusunda hem fikir 
oldukları söylenebilir. (Hussin, 2018; Mourtzis vd., 2018; Goldie, 2016 ve Harkins, 2008) çalışmalarında öğretmen ve öğretmen adaylarının Eğitim 4.0 kavramını memnuniyetle karşıladıkları ve eğitim sistemine dâhil edilmesi gerektiği konusunda ortak sonuca ulaşmışlardır. Ulaşılan bu sonuçlar yukarıda verilen ölçek sonuçlarını destekler niteliktedir. Geliştirilen ölçeğin öğretmen adaylarına daha fazla materyal kullanımı sağladığı, öğrenimi eğlenceli hale getirdiği, öğrenme sürecini teknoloji merkezli bir yapıya dönüştürdüğü ve eğitim 4.0 ile ilgili yürütülen faaliyetleri ekili kıldığı sonuçları yer almaktadır. Bu maddeler ışığında Hussin tarafından (2018) yılında yapılan çalışmada ise eğitim sistemine güncel teknolojilerin entegre edilmesi gerektiği, öğretmen ve öğretmen adaylarının dersleri tasarlama da eğitim 4.0 ile daha yaratıcı ve ilginç hale getireceğini söyleyerek verilen bu sonuçları desteklemektedir. (Hussin, 2018; Mourtzis, vd., 2018; Eichinger vd., 2017; Ciolacu vd., 2017) çalışmalarında ortak olarak öğrencilerin Eğitim 4.0 ile daha hızlı ve daha erken öğrenme gösterdiği, iş bulma imkânlarının arttı̆̆ı, eğitim 4.0 öğrenim süreci sonunda olumlu yönde geri dönütler verdiği ve önlerine çıkan sinavları kazanma ihtimallerinin daha yüksek olduğu sonucuna ulaşılmıştır. Ayrıca Eichinger vd. (2017) tarafından yapılan çalışmada eğitim 4.0'ın eğitim sisteminde yeni laboratuvar oluşturma, proje bazlı çalışma yapma ve farklı ders modülleri oluşturarak kurslara entegre edilebileceğini belirtmişlerdir. Bu çalışma sonuçları geliştirilen ölçekte yer alan "Eğitim 4.0'ın öğreticiye Etkisi” ve “Eğitim 4.0'ın Öğrenime Etkisi” faktörlerinin göstergelerini destekler niteliktedir.

Öğretmen adaylarının algı ve tutularının belirlendiği bu çalışmada öğretmen adaylarının beklentilerinin ezbere dayalı geleneksel sistem yerine teknoloji odaklı bireysel eğitim veren sistem olduğunu ve eğitimin bu yönde evrilmesi gerektiği yönündeki savunularını ortaya koymuşlardır. Yeni eğitim sistemin tasarlanmasında bu durum dikkate alınmalıdır.

Eğitim 4.0'ın Öğreticiye Etkisi Faktörü ile elde edilen bulgular değerlendirildiğinde; Eğitim 4.0 öğretmen adaylarının dijital ortamlarda iletişim kurabilmelerini, işbirlikçi çalışma yapmalarını ve çevrim içi tartışmalara aktif katılım göstererek daha kalıcı öğrenme etkinlikleri gerçekleştirebilmelerini sağlayacak ve bu sayede öğrencilerin yetenek ve kabiliyetleri ortaya çıkacaktır. Öğretmen adayları aldıkları teorik bilgilerle öğrencilerin proje bazlı çalışmalar yapmalarını, daha fazla öğretim materyali kullanmalarını sağlayarak ekip 
çalı̧̧masına yatkınlıklarını ortaya çıkaracaktır bu yüzden öğrenciler kendilerini daha rahat ifade ederek öğrendiği bilgileri günlük hayatta uygulayabileceklerdir. Eğitim 4.0 öğretmen adaylarına ders dökümanlarını daha az gayret ve hız ile hazırlama imkânı, yenileşme ve mesleki gelişim açısından firsatlar sunacaktır. Böylece Eğitim 4.0 kullanan öğretmenler doğru ilerlemeler kaydederek daha güçlü ve zeki bir nesil yetişmesini sağlayacak, öğrencilerin motivasyonunu arttırarak becerilerini geliştirecek ve onları iş hayatına hazır hale getirilmesini sağlayacaklardır.

Eğitim 4.0'ın Öğrenime Etkisi Faktörü ile elde edilen bulgular değerlendirildiğinde; Eğitim 4.0 büyük kitlelere ulaşma imkânı, bireylere uygun farklı öğrenme stilleri ve kendi hızında öğrenme programı sağlayarak öğrenci merkezli bir öğrenme ortamı sunmaktadır. Sunulan bu şartlar ile öğrencilerin öğrenim sürecinde kişisel fikirlerini daha kolay ve açı ifade edebilme becerisi kazandığı söylenebilmektedir. Ayrıca görsel, sunum, video içeriği ve eğitici oyun içerikleri ile geleneksel öğrenmeden daha etkili ve daha eğlenceli hale geleceği düşünülmektedir. Bu yüzden Eğitim 4.0 ile bilginin anlaşılması, geri çağrılması kolaylaşarak, istenildiği kadar tekrar edebilme esnekliği ile de bilgilerin kalıcı olması sağlanabilecektir.

Eğitim 4.0 Etkisi (Beklenen Fayda) Faktörü ile elde edilen bulgular değerlendirildiğinde; Eğitim 4.0 ile öğretmenler ve öğrenciler aynı sınıf ortamında bulunmalarına gerek kalmadan internet teknolojileri aracilığıyla eğitim etkinliklerini gerçekleştirebileceklerdir. Öğrenciler derse online olarak katılabilecek ya da kayıtlı ders videolarına istedikleri zaman ulaşabileceklerdir. Bu durumun zaman ve mekân kısıtlamasını ortadan kaldırarak eğitimde sürekliliği sağlayacağı düşünülmektedir. Tartışma odaları ya da e-posta gibi iletişim uygulamaları ile öğretmenler ve öğrenciler aralarında birebir işbirliği kurarak ve ders hakkında beyin fırtınası yaparak öğrenimi daha etkili hale getirebilecekleri sonucuna ulaşılabilmektedir.

Eğitim 4.0'ın Algısı Faktörü ile elde edilen bulgular değerlendirildiğinde; Algılama kapasitesi, dış dünyadaki nesneleri ve olayları yorumlama gücüdür. Öğretim hangi düzeyde yapılırsa yapılsın tüm eğitimcilerin ortak hedefi öğrencinin kendi kapasitesini etkili bir şekilde kullanmasıdır. Öğretmen adayları eğitim $4.0^{\prime} 1$ genel olarak etkili öğrenme sağlayan, fırsat eşitliği yaratan alternatif öğretim şekli olarak algılamaktadırlar. 
Eğitim 4.0'ın Uygulanabilirliği Faktörü ile elde edilen bulgular değerlendirildiğinde; Ezbere dayalı geleneksel sistemde öğrenilen bilgilerin kalıcı olmadığ 1 görülmektedir. Eğitim 4.0'ın pratiğe ve uygulamaya dayalı olması durumunda öğrencinin günün koşullarına göre kendini geliştirmesine yardımcı olacaktır. Ĕ̆itim 4.0'ın getirdiği yeniliklerden olan proje bazlı öğrenme ile öğrenilen bilgiler sadece teorikte kalmayacak gerçek projelerde uygulama imkânı bulacaktır. Eğitim 4.0 ülkemizde sağlıklı bir şekilde uygulandığında örgün eğitim uygulamalarında ortaya çıkan birçok problemin çözümünde etkili olacağı düşünülmektedir.

Eğitim 4.0'ın Sosyalleşme Etkisi Faktörü ile elde edilen bulgular değerlendirildiğinde; Eğitim 4.0'ın geleneksel eğitime sunduğu birçok avantajın yanı sıra birtakım olumsuz yönleri de bulunmaktadır. Düzenli ders çalışma alışkanlığına sahip olmayan öğrencilerin ders takibinde zorluk yaşanabilmektedir. Öğrenme süreci teknoloji merkezli bir hal aldığından teknolojik cihazlara bağımlılık artabilmektedir. Bu yüzden teknolojik aletler sadece öğrenme süreci için kullanılmalıdır. Teknolojik bağımlılığın önüne geçilmesi için kullanım amacı dışına çıkılmamalıdır. Aksi taktirde sosyal yönü zayıf nesillerin yetişmesine neden olabilecektir.

Çalışma kapsamında geliştirilen ölçek öğretmen adaylarının hem mevcut eğitim sistemi değerlendirilmesi hem de eğitim sisteminde planlanan değişim için yol gösterici olma özelliği ve önemi taşımaktadır. Ĕ̆itim alanyazınına eğitim 4.0 odağında geliştirilen ölçek olması açısından katkı sağlayacaktir.

Öğretmen adaylarından elde edilen verilerin ortak sonucu olarak İnternet ile Eğitim 4.0 faaliyetlerinin yürütülmesi, öğrencilere kendi düzeylerinde eğitim alma firsatları sunulması, görsel, video ve birçok materyal ile daha verimli ders materyalleri oluşturulacağı ve eğitimde zaman ve mekân kısıtı kaldırılarak sürekli hale getirilebileceği düşünülmektedir. Bu yüzden geleneksel eğitim sistemi yerine eğitim 4.0'ın kalıc öğrenmede, bireysel başarıda, bireylerin/öğrencilerin kendini ifade etmesinde ve mezuniyet sonrası iş imkânlarının artmasında aktif rol oynayacağı sonucuna varılmıştır. Ayrıca Eğitim 4.0 ülkemizdeki ve dünyadaki öğrenme problemlerinin çoğu Eğitim 4.0’ın getirdiği yeniliklerle çözülebilecektir. 


\title{
EXTENDED ABSTRACT
}

\section{Scale Development Study for Determining the Perceptions and Attitudes of Pre-Service Teachers towards Education 4.0}

\author{
Güler Karaman - Hilal Çalışır - Kübra Taş \\ Atatürk University
}

Industry 4.0 is the regulations that are related to production processes and foreseeing the simultaneous operation of the latest technologies through the internet (Schuh vd., 2014). It aims to offer individuals a high standard of life and future. For this reason, it needs a better equipped human workforce that adapts to technology.

Advances in the industry have also made it necessary to transition to a new education system to complement industrial requirements. After Industry 4.0; education method, student and teacher roles, educational tools and materials, content of education, in short, everything related to education has inevitably changed. This change and transformation has been named as Education 4.0 (Yalçınkaya vd., 2019).

Education 4.0, unlike traditional rote learning education systems, it is a new experience-based education system that uses technology and offers a customized education system (Yelkikalan vd., 2019). The aim of this study is to develop a scale to measure pre-service teachers' perceptions and attitudes towards the concept of Education 4.0.

In this study, a mixed method that combines qualitative and quantitative research techniques has been used. Quantitative and qualitative data collected through questionnaires were reported. Data were collected from a total of 364 pre-service teachers, 150 of whom were male and 214 of whom were female. The study was conducted in the fall semester of 2019-2020. The sample group consists of volunteer pre-service teachers who participated in the study. The highest number of participant in the study was from Atatürk University (319). In addition, pre-service teachers (75) attending to the Department of Preschool Teaching showed more interest in the study. 
During the scale development process, the scales and resources in the literature were searched with the keywords "Education 4.0, Distance education, Distance education" and the relevant items were tried to be formed. Papers, articles and theses related to the researched subject were searched through the databases of "Google Scholar", "Ebsco" "National Thesis Center" and "Scopus".

After the literature review, an item pool of 175 questions was created. The questions covering each other were removed from the item pool with the expert and the items thought to be missing were added. This process was carried out with the field expert. At the end of the process, a form consisting of items was created. The title of the form and the explanatory text to be added were decided at this stage. The final form of the scale was created by reducing the number of items to 63 with the second simplification and to 59 with the third simplification. The created form was controlled and edited by the linguist. A 5-point Likert type scale was used to evaluate the items ( $1=$ Strongly Disagree, 2 = Disagree, $3=$ Undecided, $4=$ Agree, $5=$ Strongly Agree). 53 of the items in the scale are positive, 5 are negative and one question is open-ended. The items are listed in the scale on the basis of randomness. A section consisting of 12 items containing demographic data was added to the beginning of the scale. As a result, the scale, which was created to determine the perceptions and attitudes of pre-service teachers towards Education 4.0, consists of three parts. Part one includes demographic information of the participants. In the second part, there are likert type questions. In the last part, qualitative question consisting of a single item is included.

SPSS 24.0 package program was used in the analysis of quantitative data. During the analysis process of the scale, the suitability of the data collected with the questionnaire form for factor analysis was checked with the KaiserMeyer-Olkin (KMO) coefficient and Bartlett Sphericity test (Bayram, 2004). Item-interaction score correlation, Spearman Brown split half-test correlation and Cronbach's alpha internal consistency coefficient were calculated. NVivo 12 package program was used in the analysis of the qualitative data obtained through the questionnaire. Word cloud was created with the most repetitive words. The answers to the question "What is Education 4.0?" were compiled. With the quantitative study, titles consisting of the factors including "The Effect of Education 4.0 on the Teacher", "The Effect of Education 4.0 on Lear- 
ning", "The Effect of Education 4.0 (Expected Benefit)", "Perception of Education 4.0", "The Applicability of Education 4.0" and "The Effect of Education 4.0 on Socialization" emerged. As a result of qualitative analysis, findings supporting the factors obtained after processing quantitative data were obtained.

In order to test the suitability of the quantitative data collected in this study for factor analysis, Kaiser-Meyer-Olkin coefficient (KMO - 95.9\% $(0.959>0.60)$ and Bartlett Sphericity $(0.000 \mathrm{p}<0.001)$ analyzes were performed and the results obtained were significant. Upon the scale data were found suitable for factor analysis, in order to examine the construct validity and factor structure of the Education 4.0 Perception and Attitude Scale exploratory factor analysis were used. In addition, as a factoring technique, principal component analysis were also used. Relationships between items are examined. In order to define factors, correlations of relationships between variables must be determined and the variable group must be related to each other. Unrelated factors should be removed as they present difficulties (Hutcheson ve Sofroniou, 1999). As shown in Table 1 representing the results of these analyzes, the number of items was reduced to 38 .

Table 7. Removed Questions According to Exploratory Factor Analysis

\begin{tabular}{lll}
\hline Stages & & Removed Questions \\
\hline $\mathbf{1 .}$ & Stage & $53,37,27,34,38,58,10,56$ \\
2. & Stage & $28,31,35,40,39,30,29,9,1$ \\
3. & Stage & 32,26 \\
4. & Stage & 25 \\
\hline
\end{tabular}

The KMO and Barlett test values of the questionnaire form consisting of 38 items was found to be 0.944 and 7226.728 recpectively. As a next step, the reliability of the developed scales were tested with the Croanbach Alpha (0.948) and Spearman Brown (0.836) tests. The questionnaire form was reorganized visually by examining the contents of the items. Six factors emerged in line with the relationship between scale items and their factors. Factors and indicators of each factor were given as a result of factor analysis (see Table 6).

Within the scope of this study, a scale was developed to determine the perceptions and attitudes of pre-service teachers' towards education 4.0. 'Effect of Education 4.0 on Teacher', 'Effect of Education 4.0 on Learning', 'Education 4.0 Effect (Expected Benefit)', 'Perception of Education 4.0', 'Applicabi- 
lity of Education 4.0' and 'Socialization Effect of Education 4.0' are the six factors that extracted according to the quantitative analysis and composed the scale. The qualitative findings also supports these six factors.

\section{Kaynakça / References}

Abdelrazeq, A., Janssen, D., Tummel, C., Richert, A. S. ve Jeschke, S. (2016). Teacher 4.0: Requirements of the teacher of the future in context of the fourth industrial revolution. Conference Proceedings of the 9th International Conference of Education, Research and Innovation içinde (s. 8221-8226). Spain : Seville.

Aberšek, B. ve Flogie, A. (2017). Evolution of competences for new era or education 4.0. In XXV Conference of Czech Educational Research Association (CERA/ČAPV)"Impact of Technologies in the Sphere of Education and Educational Research. Czech.

Bayram, N. (2004). Sosyal bilimlerde spss ile veri analizi. Bursa: 4 Nokta Matbaacilık Ltd.

Büyüköztürk, Ş. (2005). Anket geliştirme. Türk Eğitim Bilimleri Dergisi, 3(2), 133-151.

Büyüköztürk, Ş., Çakmak, K. E., Akgün, E. Ö., Karadeniz, Ş. ve Demirel, F. (2010). Scientific research methods. Ankara: PEGEM Akademi.

Chea, C. C. ve Huan, J. T. (2019). Higher education 4.0: The possibilities and challenges. Journal of Social Sciences and Humanities, 5(2), 81-85.

Ciolacu, M., Tehrani, A. F., Beer, R. ve Popp, H. (2017). Education 4.0:Fostering student's performance with machine learning methods. In 2017 IEEE 23rd International Symposium for Design and Technology in Electronic Packaging (SIITME) (s. 483443). IEEE.

Commissioan, E. (2017). Education 4.0. Avusturya: Mobile Learning Key Messages of PLA\# 5. Viyana.

Creswell, J. (2017). Karma yöntem araiştırmalarna giriş. (M. Sözbilir, Dü., \& M. Sözbilir, Çev.) Ankara: PEGEM Akademi.

Demir, A. (2018). Endüstri 4.0'dan Eğitim 4.0’a değişen eğitim öğretim paradigmaları. Electronic Turkish Studies, 13(15).

Eichinger, P., Hofig, B. ve Richter, C. (2017). Education 4.0 for Mechatronics: Agile and Smart. 2017 International Conference on Research and Education in Mechatronics (REM) içinde (s. 1-7). IEEE.

Eldem, M. O. (2017). Endüstri 4.0. TMMOB EMO Ankara Şubesi Haber Bülteni: 16 Aralik $2019 \quad$ tarihinde http://www.emo.org.tr/ekler/09287020c96f18a ek.pdf?dergi=1111 adresinden erişildi.

Goldie, J. G. (2016). Connectivism: A knowledge learning theory for the digital age? Medical Teacher, 38(10), 1064-01069. 
Greene, J. C., Krayder, H. ve Mayer, E. (2005). Combining qualitative and quantitative methods in social inquiry. B. Somekh ve C. Lewin (Dü), Research Methods in The Social Sciences içinde (s. 275-282). London: SAGE Publication.

Harkins, A. M. (2008). Leapfrog principles and practices: Core components of education 3.0 and 4.0. Futures Research Quarterly, 24(1), 19-31.

Hussin, A. A. (2018). Education 4.0 made simple: Ideas for teaching. International Journal of Education and Literacy Studies, 6(3), 92-98.

Hutcheson, G. ve Sofroniou, N. (1999). The multivariate social scientist: Introductory statistics using generalized linear models. Thousand Oaks, CA: Sage Publications.

Karaman, G. (2015). Canlı ders etkileşim belirleme ölçeŏinin geliştirilmesi ve otomatik kestirim sisteminin tasarlanması. Erzurum: Atatürk Üniversitesi, Doktora Tezi.

Karataş, H. (2017, Ocak 21). Endüstri 4.0'ın eğitim 4.0'a yansımaları. Marmara Gazetesi. 16 Aralık 2019 tarihinde http://www.marmaragazetesi.com/endustri-4-0in-egitim-4-0a-yansimalari-981yy.htm adresinden erişildi.

Lasi, H., Fettke, P., Kemper, H.-G., Feld, T. ve Hoffmann, M. (2014). Industry 4.0. Business $\mathcal{E}$ Information Systems Engineering, 6(4), 239-242.

Mourtzis, D. (2018). Development of skills and competences in manufacturing towards education 4.0: A teaching factory approach. International Conference on the Industry 4.0 model for Advanced Manufacturing (s. 194-210). Cham: Springer.

Mourtzis, D., Vlachou, E., Dimitrakopoulos, G. ve Zogopoulos, V. (2018). Cyber-physical systems and education 4.0-the teaching factory 4.0 concept. Procedia Manufacturing, 23, 129-134.

Öztemel, E. (2018). Eğitimde yeni yönelimlerin değerlendirilmesi ve eğitim 4.0. Üniversite Araştırmalan Dergisi, 25-30.

Prieto, M. D., Sobrino, Á. F., Soto, L. R., Romero, D., Biosca, P. F. ve Martínez, L. R. (2019). Active learning based laboratory towards engineering education 4.0. In 2019 24th IEEE International Conference on Emerging Technologies and Factory Automation (ETFA) (s. 776-783). IEEE.

Puncreobutr, V. (2016). Education 4.0: New challenge of learning. St. Theresa Journal of Humanities and Social Sciences, 2(2).

Ratcliff, D. (2008). Qualitative data analysis and the transforming moment. Transformation, 25((2-3)), 116-133.

Şener, S. ve Elevli B. (2017). Endüstri 4.0'da yeni iş kolları ve yüksek öğrenim. Mühendis Beyinler Dergisi, 1(2), 1-13.

Schuh, G., Potente, T., Wesch-Potente, C., Weber, A. ve Prote, J.-P. (2014). Collaboration mechanisms to increase productivity in the context of industrie 4.0. Procedia CIRP, 19, 51-56. 
Silverman, D. (2001). Interpreting qualitative data: Methods for analysing talk, text and interaction. London: SAGE Publications.

Storey, L. (2007). Doing interpretative phenomenological analysis. L. E., \& C. A. (Dü), Analysing Qualitative Data In Psychology içinde (s. 51-64). Los Angels: SAGE Publications.

Strauss, A. ve Corbin, J. (1990). Basics of qualitative research: Grounded theory procedures and techniques. New Delhi: SAGE Publications.

Yalçınkaya, D., Korkmaz, S. ve Karataş, A. (2019). Endüstri 4.0 ile değişen ve gelişen eğitim yapısı. Education structure Changing and Developing with Industry 4.0.

Yelkikalan, N.,Erden-Ayhün, S., Aydın, E. ve Kurt, Ü. (2019). Endüstri 4.0'dan eğitim 4.0’a yükseköğretimin geleceği. 4. Uluslararası Yüksseköğretim Çalışmalan Konferansı,IHEC, 123-125.

\section{Kaynakça Bilgisi / Citation Information}

Karaman, G., Çalışır, H. ve Taş, K. (2020). Öğretmen adaylarının eğitim 4.0'a karşı alg1 ve tutumlarının belirlemesine yönelik ölçek geliştirme çalışması. OPUS-Uluslararası Toplum Araştırmaları Dergisi, 16(31), 4156-4185. DOI: 10.26466/opus.691488 